\title{
Turizm Öğrencilerinin Turizm Sektörüne Yönelik Algılarının Sektörde Kalma Niyetlerine Etkisi: ESOGÜ Turizm Fakültesi Örneği
}

\author{
Serpil KAYA, Yasin Emre OĞUZ, Veysel YILMAZ*
}

Turizm Öğrencilerinin Turizm Sektörüne Yönelik Algılarının Sektörde Kalma Niyetlerine Etkisi: ESOGÜ Turizm Fakültesi Örneği

\section{Özet}

Bu araştırma turizm öğrencilerinin turizm sektörüne yönelik algılarının sektörde kalma niyetleri üzerindeki etkisini belirlemek amacıyla hazırlanmıştır. Modeldeki yapısal ilişkilerin sınanmasında kullanılan veriler, Eskişehir Osmangazi Üniversitesi Turizm Fakültesi ( $n=397$ ) yüz yüze anket yapılarak elde edilmiştir. Araştırmanın devamında, içsel gizil değişken olarak "sektörde kalma niyeti" ve dışsal gizil değişkenlerin de "işin doğası", "fiziksel çalışma koşulları", "sosyal statü", "ücret", "yöneticiler" ve "promosyon fırsatları" olarak betimlendiği yapısal eşitlik modeli ile kurulmuştur. Araştırma sonucunda; işin doğası, fiziksel çalışma koşulları, sosyal statü, ücret, yöneticiler ve promosyon fırsatlarının sektörde kalma niyeti üzerinde istatistiksel olarak anlamlı bir etkisi olduğu tespit edilmiştir. Araştırma kapsamında kurulan model desteklenmiştir.

Anahtar Kelimeler: Turizm Sektörü Algısı, Sektörde Kalma Niyeti, Yapısal Eşitlik Modellemesi, Öğrenciler, Eskişehir

Makale Türü: Araştırma

1. Giriş

Turizm insanların gezme, görme ve keşfetme gibi ihtiyaçlarının bir sonucu olarak doğan sosyal bir olgu olarak kabul edilmektedir (Kozak vd., 2014: 1). Konaklama, seyahat, ulaştırma, eğlence ve yiyecek-içecek gibi çeşitli faaliyet alanlarından oluşan turizm sektörü,

*Serpil KAYA, Doktora Öğrencisi., Eskişehir Osmangazi Üniversitesi, Sosyal Bilimler Enstitüsü, serpill_kayaa@hotmail.com.tr, ORCID ID orcid.org / 0000-0003-3430-7169 Yasin Emre OĞUZ, Arş. Gör., Eskişehir Osmangazi Üniversitesi, Turizm İşletmeciliği Bölümü, yeoguz@ogu.edu.tr, ORCID ID orcid.org / 0000-0002-2139-4278, Veysel YILMAZ, Prof. Dr., Eskişehir Osmangazi Üniversitesi, İstatistik Bölümü, vyilmaz@ogu.edu.tr, ORCID ID orcid.org / 0000-0001-5147-5047. Araştırma verilerinin toplanmasında kullanılan anket formu için ESOGÜ Sosyal ve Beşeri Bilimler Bilimsel Araştırma ve Yayın Etiği Kurulu Başkanlığı'ndan 08.04.2020 tarihinde (belge sayı no: 2020-08) etik kurul onayı alınmıştır.

Makale Gönderim Tarihi 26/03/2020

Makale Kabul Tarihi $\quad 17 / 06 / 2020$
The Effects of the Perceptions of Tourism Students Case of ESOGU Tourism Faculty Students

Abstract

This research aims to determine the effects of the perceptions of tourism students towards the tourism sector on their intention work. This research data which is used in order to test the al relationship between the variables are collected from through a face to face survey method $(n=397)$. This recommended model consisted of nature of work, physical working conditions, social status, fee, managers, promotion opportunities as the exogenous latent variables and intention to work as the endogenous latent variable. As a result of the research; it was determined that the nature of work, physical opportunities effect on intention to work with participants.

Keywords: Perception of Tourism Sector, Intention to Work, Structural Equation Modeling, Students, Eskisehir

Paper Type: Research Towards the Tourism Sector on their Intention to Work: 
küreselleşen dünya ile birlikte hızla büyüyen bir sektör haline gelmiştir (Şit, 2016: 115-116). Turizm sektörünün emek yoğun özelliği insan faktörünün önemini daha da ön plana çıkarmaktadır (Haven-Tang ve Jones, 2008: 353; Hayes ve Ninemeier, 2008: 5). Diğer bir ifadeyle, turizm sektöründe hizmetin makineleştirilmesi ve otomasyona dönüştürülmesi olanağı diğer sektörlere oranla çok daha sınırlı kalmaktadır. Bunun temelinde ise turistik ürünün taşıdığı soyut özellikler yer almaktadır. Her ne kadar teknolojik yenilikler yaşansa da turizm sektöründe birçok iş alanında hala insan emeğine ihtiyaç duyulmaktadır (Szivas vd., 2003: 64).

Turizm sektöründe sunulan ürün ve hizmetlerin kalitesi insanla ilgilidir ve hizmet kalitesinin odak noktasını yine insan gücü oluşturmaktadır. Bu açıdan turizm sektöründe hizmet kalitesinin arttırılması için öncelikle nitelikli iş gücünün planlanması gerekmektedir (Erbaş vd., 2013: 1151). Turizm eğitim ve öğretimi, mesleki teknik eğitim çerçevesinde değerlendirilmektedir (Şahin ve Fındık, 2008: 65). Turizm eğitim kurumlarının temel amaçları ise turizm sektöründe çalışacak olan personellerin temel eğitimini sağlamak, tüm eğitim alanlara turizm bilincini ve felsefesini kazandırmak ve turizm sektörüne kalifiye personel yetiştirmek şeklinde ifade edilmektedir (Baltacı vd., 2012: 18). Ancak turizm sektöründe iş gücü ihtiyacının büyük bir bölümü kalifiye olmayan iş gücü istihdam edilerek sağlanmakta ve bu durum hizmet kalitesinin düşmesine neden olmaktadır. Bu nedenle, işletmeler ekonomik fayda elde etmekte zorlanmaktadır (Erbaş vd., 2013).

Günümüz turizm öğrencileri geleceğin turizm sektörü çalışanları olmak için eğitim ve öğretim hayatına devam etmektedir (Türker vd., 2016). Ancak bu husus da yapılan çalışmalar, turizm öğrencilerinin sadece \%30'luk bir bölümünün sektörde devam ettiğini göstermektedir (Köşker ve Unur, 2017; Temizkan vd., 2019). 2019 yılında Türkiye genelinde 133 üniversitede yaklaşık 32 bin turizm kontenjanı açıldığı bilinmektedir (Turizm Akademisyenleri Derneği, 2020). Bu kadar yatırım yapılan ve kontenjan açılan okullardan mezun olanların yarısından azının sektörde devam etmesi ise durumun vahametini gözler önün sermektedir. Bu nedenle turizm öğrencilerinin mezun olduktan sonra kariyerlerine nasıl devam edeceklerinin tespit edilmesi yapılan bu araştırmanın çıkış noktası ve problemini oluşturmaktadır. Bu çalışma ile Eskişehir Osmangazi Üniversitesi turizm öğrencilerinin turizm sektörüne yönelik algılarının turizm sektöründe kalma niyetleri üzerindeki etkisinin belirlenmesi amaçlanmaktadır. Buradan hareketle, öğrencilerin sektörde kalma niyetlerini olumsuz yönlü etkileyen faktörlere yönelik çözüm önerileri geliştirilmiştir. Bu durum hem araştırmanın önemini hem de özgün değerini oluşturmaktadır. Ayrıca öğrencilerin sektör kalma niyetlerini ölçen bir model geliştirmenin de literatüre katkı sağlayacağı düşünülmektedir. 


\section{Kavramsal Çerçeve}

Turizm sektörü özellikle gelişmekte olan ülkeler açısından önemli bir istihdam kaynağı olarak kabul edilmektedir. Ancak sektörde çalışanların memnuniyetlerinin ve aldıkları ücretlerin düşük olması nedeniyle de eleştirilmektedir (Roney ve Öztin, 2007: 5). Bu durum turizm sektörünü kalifiye personelleri cezbetme ve elde tutma sorunu ile karşı karşıya bırakmıştır. Bugünün öğrencileri yarının etkili uygulayıcıları ve sektör çalışanları olacakları için turizm sektörü ile ilgili algılarının ölçülmesi ve gelecek planlamalarının bu sonuçlara göre yapılması gerekmektedir (El-Houshy, 2014: 800). Bu açıdan turizm ve konaklama sektöründe yetenekli, hevesli ve kararlı bir iş gücüne sahip olmak özelde sektördeki firmaların başarısı genelde de Türkiye ekonomisi için hayati bir önem taşımaktadır (Kusluvan ve Kusluvan, 2000: 61).

İşletme çalışanları arasında etkin bir performans sergilemeyi hedefleyen insan kaynakları yönetiminde, personelin işletme ile olan ilişkisini belirleme noktasında kariyer kavramı devreye girmektedir (Greenhaus ve Callanan, 2006: 61). Literatürde birçok tanımı yapılmış olan kariyer kavramı 1960'lı yıllardan önce nadiren kullanılmaktaydı (Herr, 2001: 196). Genellikle kişilerin iş hayatıyla eş anlamlı olarak kullanılan bir kavramdı (Brown vd., 2004: 5). Ancak gerçekte kariyer kavramı, iş hayatının ve sosyal yaşamın çalışanların hayatındaki önemi ile ilişkilendirilmektedir (Burack, 1988: 39). Kariyer; bireylerin yaşam süreleri boyunca kurum içinde ve kurum dışında işle ilgili deneyimleri şeklinde ifade edilmektedir. Ayrıca kariyer; ulusal kültür, ekonomi, siyasi çevre gibi birçok bağlamsal ve başkalarıyla ilişkiler gibi kişisel faktörlerden etkilenmektedir (Sullivan ve Baruch, 2009, s. 1543).

Kariyer yönetimi ise bir kurum içindeki bireylerin ilerleyişini; örgütsel ihtiyaç ve örgütsel hedeflere, çalışanların performans potansiyeline ve tercihlerine göre planlayan ve şekillendiren süreç olarak tanımlanmaktadır (Hartzenberg, 2002). Diğer bir ifadeyle bireylerin ilgi alanları, becerileri, güçlü ve zayıf yönleri hakkında bilgi topladığı bir kariyer hedefi belirlediği ve kariyer hedeflerine ulaşma olasılığını artıran kariyer stratejilerine dâhil olduğu bir süreci ifade etmektedir. Bu süreç kariyer araştırması, kariyer hedeflerinin geliştirilmesi ve kariyer hedeflerine ulaşmak için kariyer stratejilerinin kullanılmasını içermektedir (Patrick ve Kumar, 2011: 2). Bireylerin kariyer yönetimini hangi süreçler olarak tanımladıkları ise aşağıdaki gibi sıralanmaktadır (Hartzenberg, 2002: 6):

$>$ Kendisi ve iş dünyası ile ilgili bilgileri toplar.

$>$ Yetenekleri, ilgileri, değerleri ve tercih edilen yaşam tarzı ile alternatif meslekler ve organizasyonlar hakkında doğru bir resim geliştirir.

$>$ Gerçekçi kariyer hedefleri yaratır.

$>$ Hedeflere ulaşmak için tasarlanmış bir strateji geliştirir ve bu stratejiyi uygular.

$>$ Stratejinin etkinliği ve hedeflerin uygunluğu hakkında geri bildirim sağlar. 
Kariyer ile ilgili diğer bir önemli kavramda kariyer niyetidir. Kariyer niyeti bir kişinin kariyerini bilinçli bir şekilde belirli bir gelecek davranışı için planlaması şeklinde ifade edilmektedir (Warshaw ve Davis, 1985: 214). Insanların kariyer seçimleri ekonomi için de hayati bir öneme sahiptir. Bu açıdan kariyer niyetlerini neyin veya nelerin etkilediğini anlamak çok önemlidir (Gunawardena vd., 2018: 7). Öğrencilerin kariyer niyetleri ise kariyer planlarında yaş, cinsiyet, akademik performans gibi demografik değişkenleri dikkate alarak hem kısa hem de uzun vadede ne yapmak istediklerini anlamak üzerine yoğunlaşmaktadır (Cano vd., 2017: 2). Öğrencilerin okullarını bitirdikten sonra beklentilerinin ve kariyer niyetlerinin ve sektörde kalma niyetlerinin etkili bir şekilde analiz edilmesinin hem öğrencilere hem de işletmelere fayda sağlayacağı düşünülmektedir (Farmaki, 2018: 52). Bu nedenle yapılacak olan bu araştırma hem sektör için hem de öğrenciler için büyük bir önem arz etmektedir. Bu araştırmanın çıkış noktasını da bu fikir oluşturmaktadır.

Roney ve Öztin (2007) tarafından yapılan araştırmada Boğaziçi, Bilkent ve Anadolu Üniversitesinde öğrenim gören turizm lisans öğrencilerinin kariyer algıları incelenmiştir. Araştırma kapsamında 450 öğrenciye anket uygulanmıştır. Araştırmanın analiz aşamasında ise sıralayıc ifadelerden ve frekans analizlerinden yararlanılmıştır. Araştırma sonucunda katılımcıların turizm sektöründe çalışmaya istekli olmasının mezuniyet sonrasında sektörde devam etme niyetine olumlu etkisi olduğu görülmüştür. Chuang ve Dellmann-Jenkins (2010) tarafından yapılan araştırmada turizm lisans öğrencilerinin turizm sektöründeki kariyer niyetlerini etkileyen faktörler incelenmiştir. Bu kapsamda 360 katılımcıya anket uygulanmıştır. Araştırma sonucunda sektördeki kariyer niyetlerinin; öğrencilerin cinsiyetleri, iş tecrübeleri, transfer durumu ve sektördeki beklentilerine göre anlamlı farklılık gösterdiği tespit edilmiştir. Araştırmanın diğer bir sonucu da kariyer niyetlerinin kariyer başarılarını olumlu yönde etkileyeceği ve kendilerini gerçekleştirme fırsatlarını daha da arttıracağı olmuştur. Richardson (2010) tarafından yapılan araştırmada turizm öğrencilerinin kariyer algıları ile uluslararası ve yerli öğrencilerin kariyerlerine yönelik görüşlerindeki farklılıklar analiz edilmiştir. Araştırmada 379 katılımcıya anket uygulanmıştır. Araştırma sonuçlarında iki grup arasında önemli farklılıklar olduğu belirlenmiştir. Uluslararası öğrencilerin kariyer seçiminde sektörü önemli buldukları tespit edilirken, yerli öğrencilerin ise mezun olduktan sonra sektörde devam etme olasılıklarının düşük olduğu tespit edilmiştir.

Öğrencilerin sektörde çalışma niyetlerinin incelenmesine yönelik diğer bir araştırmada El-Houshy (2014) tarafından yapılmıştır. Bu araştırmada öğrencilerin sektörde çalışmalarına ilişkin algıları incelenmiştir. Veri toplamak için anket tekniğinden yararlanılmıştır. Araştırma kapsamında 85 katılımcıya anket uygulanmıştır. Araştırma sonucunda katılımların turizm sektörünü kariyerleri için önemli buldukları ve mezun olduktan sonra sektörde devam etmek istedikleri belirlenmiştir. Bu hususta yapılan diğer bir araştırmada Türker, Uçar ve Ateş (2016) tarafından Karabük Üniversitesi öğrencilerine 
yönelik olarak yürütülmüştür. Yapılan araştırmada turizme yönelik algılar; çalışma koşulları, sosyal statü, yöneticiler, ücret, promosyon, motivasyon ve özel hayat başlıkları altında ele alınmıştır. Araştırmada anket yönteminden yararlanılmış ve 393 katılımcıya yüz yüze anket uygulanmıştır. Araştırma bulguları fark testleri aracılığıyla incelenmiştir. Araştırma sonucundan öğrencilerin sektörü çalışma koşulları ve sosyal statü açısından olumsuz algıladıkları görülmüştür.

Gunawardena ve diğerleri (2018) tarafından yapılan araştırmada lisans öğrencilerinin kariyer niyetleri planlı davranış teorisi aracılığıyla incelenmiştir. Yapılan araştırmada ayrıca öğrencilerin demografik ve sosyo-ekonomik özelliklerinin kariyer niyetleri üzerindeki etkileri araştırılmıştır. Araştırma sonucunda tutumların, öznel normların ve planlı davranış teorisinin kamu ve özel sektördeki kariyer niyetiyle ve kendi işletme girişimlerinde önemli bir etkisi olduğunu ortaya koymuştur. Diğer taraftan özel sektördeki kariyer niyeti, son sınıf ve birinci sınıf öğrencileri arasında önemli ölçüde farklılık göstermiştir. Kariyer niyeti, tutumları, öznel normlar ve özel sektöre yönelik planlı davranış teorisi, erkekler ve kadınlar arasında önemli bir fark göstermiştir, ancak işe başlayanlar için aynı durum söz konusu olmamıştır. Kamu sektöründe kariyer niyetine ilişkin tutum, kentli ve kırsaldan gelen öğrenciler arasında önemli bir farklılık göstermiştir. Özel sektörde kariyer niyeti ve özel sektöre yönelik tutum ve planlı davranış teorisi, kentli ve kırsaldan gelen öğrenciler arasında önemli bir farklılık olarak bulunmuştur. Temizkan ve diğerleri (2019) tarafından turizm sektöründe durum tespitine yönelik bir araştırma yürütülmüştür. Araştırmanın veri toplama aşamasında yarı yapılandırılmış görüşme formundan yararlanılmıştır. Araştırma sonucunda katılımcıların \%36'sının mezuniyet sonrasında turizm sektöründe devam ettikleri tespit edilmiştir. Ayrıca katılımcıların \%73'ünün çevrelerine turizm eğitim ve öğretimini tavsiye etmeyecekleri sonucuna ulaşılmıştır.

Bu araştırmada ise Eskişehir Osmangazi Üniversitesi Turizm Fakültesi'nde öğrenim gören öğrencilerin turizm sektörü ile ilgili algılarının sektörde kalma niyeti üzerine etkileri incelenmiştir. Araştırmada katılımcıların turizm sektörüne yönelik algıları; işin doğası, fiziksel koşulları, sosyal statü, ücret, yöneticiler ve promosyon fırsatları (Kusluvan ve Kusluvan, 2000; Richardson, 2010; El-Houshy, 2014) şeklinde altı boyut altında ele alınmıştır. İlgili değişkenler dışsal gizil değişken olarak araştırma modeline eklenmiştir. Devamında ise araştırma kapsamında, içsel gizil değişken olan sektörde kalma niyetine (Reigel ve Dallas, 1998) etkileri yapısal eşitlik modellemesi aracılığıyla incelenmiştir.

\section{Yöntem}

Araştırmada turizm işletmeciliği öğrencilerinin turizm sektörüne ilişkin algılarının sektörde kalma niyetlerine etkisi incelenmiştir. Araştırmada veri toplama yöntemi olarak ise nicel araştırma yöntemlerinden anket tekniği kullanılmıştır. Araştırma verilerinin toplanmasında kullanılan anket formu için ESOGÜ Sosyal ve Beşeri Bilimler Bilimsel 
Araştırma ve Yayın Etiği Kurulu Başkanlığı'ndan etik kurul onayı alınmıştır. Ayrıca verilerin analiz edilmesinde SPSS 24 ve Lisrel 8.80 paket programları kullanılmıştır.

\subsection{Araştırma Evreni ve Örneklemi}

Araştırmanın evreni 2019-2020 eğitim öğretim döneminde Eskişehir Osmangazi Üniversitesi Turizm Fakültesi öğrenim görmekte olan ve daha önce staj yapmış veya bir turizm işletmesinde çalışmış öğrencilerden oluşmaktadır. Evrende yer alan tüm öğrencilere ulaşmak zaman ve maliyet açısından mümkün olmadığı için araştırma örneklemi belirlenmesine karar verilmiştir. ESOGÜ Turizm Fakültesi öğrenci işlerine sorulduğunda, 2019-2020 eğitim öğretim döneminde ders kaydı yaptırmış ve aktif olarak öğrenciliğe devam eden 986 lisans öğrencisi olduğu belirlenmiştir. Buradan hareketle, en az 278 katılımcıya anket uygulanması gerektiğine karar verilmiştir (Çıngı, 2009). Anketler, hem birinci öğretim hem de ikinci öğretim öğrencilerine ve 4 yıllık lisans düzeyindeki tüm sınıflara yüz yüze şekilde uygulanmıştır. Ayrıca araştırma açısından önemli bir husus da katılımcıların daha önce staj yapmış ya da bir turizm işletmesinde çalışmış olmasıdır. Bu nedenle, anket formları dağıtılırken öncelikle öğrencilere bu soru yöneltilmiş ve olumlu cevap alınanlara 400 adet anket dağıtılmıştır. Bu anketlerden eksiksiz olarak doldurulan 397 adedi analiz için kullanılmıştır.

\subsection{Araştırmanın Modeli ve Hipotezler}

Araştırma kapsamında kurulan model, Kusluvan ve Kusluvan (2000) tarafından kullanılan araştırma modelinde yer alan işin doğası, fiziksel çalışma koşulları, sosyal statü, ücret, yöneticiler, promosyon fırsatları dışsal gizil değişkenlerine (Richardson, 2010; ElHoushy, 2014), Riegel ve Dallas'ın (1998) sektörde kalma niyeti içsel gizil değişkeninin eklenmesiyle oluşturulmuştur. Buradan hareketle, önerilen araştırma modeli ise aşağıdaki gibidir:

Şekil 1. Araştırma Modeli

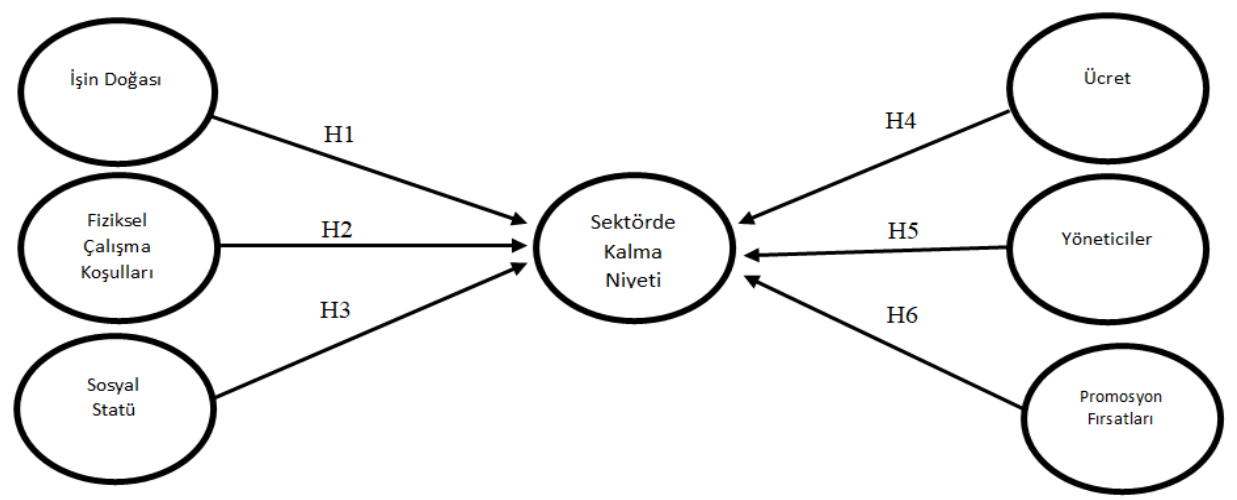


Şekil 1'de yer alan araştırma modeline dayandırılarak aşağıdaki hipotezler kurulmuştur:

H1: İşin doğasına yönelik algının sektörde kalma niyeti üzerine istatistiksel olarak anlamlı bir etkisi vardır.

H2: Fiziksel çalışma koşullarına yönelik algının sektörde kalma niyeti üzerine istatistiksel olarak anlamlı bir etkisi vardır.

H3: Sosyal statüye yönelik algının sektörde kalma niyeti üzerine istatistiksel olarak anlamlı bir etkisi vardır.

H4: Ücrete yönelik algının sektörde kalma niyeti üzerine istatistiksel olarak anlamlı bir etkisi vardır.

H5: Yöneticilere yönelik algının sektörde kalma niyeti üzerine istatistiksel olarak anlamlı bir etkisi vardır.

H6: Promosyon fırsatlarına yönelik algının sektörde kalma niyeti üzerine istatistiksel olarak anlamlı bir etkisi vardır.

\subsection{Veri Derleme Aracı}

Araştırma verilerinin toplanmasında kullanılan anket iki bölümden oluşmaktadır. Anketin birinci bölümünde katılımcıların demografik özelliklerini belirlemeye yönelik ifadeler bulunmaktadır. Anketin ikinci bölümünde ise işin doğası, fiziksel çalışma koşulları, sosyal statü, ücret, yöneticiler, promosyon fırsatları ve sektörde kalma niyetine yönelik $5^{\prime} l i$ likert tipinde derecelendirilmiş 25 ifade yer almaktadır (1= Hiç katılmıyorum, $2=A z$ Katılıyorum, 3= Orta Düzeyde Katılıyorum, 4= Çok Katılıyorum, 5= Tamamen katılıyorum). Araştırmada kullanılan ölçek literatürde yer alan çalışmalardan derlenmiştir (Riegel ve Dallas, 1998; Kusluvan ve Kusluvan, 2000; Richardson, 2010; El-Houshy, 2014).

\section{Bulgular}

Araştırmanın bulgular aşamasında öncelikle toplanan veriler tanımlayıcı istatistikler aracılığıyla tablolaştırılmış ve yorumlanmıştır. Analizin devamında ölçekte yer alan ifadelerin geçerlilik ve güvenilirlik analizi bulgularına bakılmıştır. Analizin diğer bir aşaması ise faktör analizidir. Araştırmada toplanan verilere sırasıyla açıklayıcı faktör analizi ve doğrulayıcı faktör analizi yapılmıştır. Yapılan analiz sonucunda 7 adet faktör belirlenmiştir. İlgili faktörler literatürde yer alan çalışmalara dayandırılarak; işin doğası, fiziksel çalışma koşulları, sosyal statü, ücret, yöneticiler, promosyon fırsatları ve sektörde kalma niyeti şeklinde isimlendirilmiştir (Riegel ve Dallas, 1998; Kusluvan ve Kusluvan, 2000; Richardson, 2010; El-Houshy, 2014). Analizin son aşamasında ise faktörler arası çoklu ilişkiler yapısal eşitlik modellemesi (Çelik ve Yılmaz, 2016) ile incelenmiştir. 


\subsection{Katılımcıların Demografik Özelliklerine Yönelik Bulguları}

Analizin ilk aşamasında cinsiyet, yaş, öğrenim süresi ve sektörde çalışma süreleri gibi demografik özelliklerine ilişkin bulgular yorumlanmıştır.

Tablo 1: Katılımcıların Demografik Özelliklerine Yönelik Bulgular

\begin{tabular}{lll}
\hline \hline Cinsiyet & Sayı & Yüzde (\%) \\
Erkek & 209 & 52,6 \\
Kadın & 188 & 47,4 \\
\hline Yaş & Sayı & Yüzde (\%) \\
$18-20$ yaş arası & 120 & 30,2 \\
$21-23$ yaş arası & 104 & 26,2 \\
$24-26$ yaş arası & 99 & 24,9 \\
27 yaş ve üzeri & 74 & 18,6 \\
\hline Öğrenim Süresi & Sayı & Yüzde (\%) \\
1 yıl & 41 & 10,3 \\
2 yıl & 99 & 24,9 \\
3 yıl & 95 & 23,9 \\
4 yıl & 92 & 23,2 \\
5 yıl ve üzeri & 70 & 17,6 \\
\hline Sektörde Çalışma Süresi & Sayı & Yüzde (\%) \\
1 yıldan az & 146 & 36,8 \\
$1-3$ yıl arası & 139 & 35,0 \\
4 yıldan fazla & 112 & 28,2 \\
\hline Toplam & 397 & 100
\end{tabular}

Tablo 1'de katılımcıların demografik özelliklerine yönelik bulgular yer almaktadır. Buna göre katılımcıların \%52,6'sı (209) erkek öğrencilerden, \%47,4'ü (188) kız öğrencilerden oluşmaktadır. Ayrıca katılımcıların \%30,2' sinin (120) 18-20 yaş arasında, \%26,2'sinin (104) 21-23 yaş arasında, \%24,9'unun (99) 24-26 yaş arasında ve 18,6'sının (74) 27 yaş ve üzerinde oldukları tespit edilmiştir. Turizm sektörünün doğası gereği birçok öğrencinin hem sektörde çalışıp hem de eğitim öğretime devam ettiğinden dolayı yaş dağılımlarının bu şekilde olduğu düşünülmektedir. Araştırma kapsamında katılımcılara sorulan diğer bir demografik soru da Eskişehir Osmangazi Üniversitesi Turizm Fakültesi'nde kaç yıldır eğitim gördükleridir. Buna göre katılımcıların \%10,3’ü (41) 1 yıldır, \%24,9’u (99) 2 yıldır, \%23,9’u (95) 3 yıldır, \%23,2'si (92) 4 yıldır ve \%17,6’sı (70) 5 yıl ve üzeri süredir turizm işletmeciliği okumaktadır. Ayrıca katılımcıların \%36,8'i (146) 1 yıldan az, \%35'i (139) 1 - 3 yıl arası, $\% 28,2$ 'si (112) ise 4 yıldan fazla sektör deneyimine sahiptir (Tablo 1). 


\subsection{Geçerlilik ve Güvenilirlik Analizine Yönelik Bulgular}

Araştırma kapsamında toplanan verilerin güvenilirliğini değerlendirmek büyük önem teşkil etmektedir. Cronbach Alfa yaygın olarak kullanılmakta olan bir güvenilirlik endeksidir. $\mathrm{Bu}$ nedenle ölçekte yer alan ifadelerin değerlendirilmesinde önemli bir işlevi bulunmaktadır (Tavakol ve Dennick, 2011: 54). Ölçekte bulunan ifadelerin homojen yapısını açıklamak ya da sorgulamak üzere kullanılan bu analiz Likert tipi ölçeklerde sıklıkla kullanılmaktadır (Yıldız ve Uzunsakal, 2018: 19). Güvenilirlik ve ölçek ile ilgili diğer analizlere başlamadan önce ölçekte yer alan olumsuz ifadelerin SPSS programı aracılığıyla ters kodlamaları yapılmıştır. Devamında ise güvenilirlik analizi bulguları incelenmiştir (Tablo 2).

Tablo 2. Güvenilirlik Analizi Bulguları

\begin{tabular}{cccc}
\hline \hline IFADELER & ORTALAMA & $\begin{array}{c}\text { STANDART } \\
\text { SAPMA }\end{array}$ & $\begin{array}{c}\text { CRONBACH'S ALPHA } \\
\text { Çıkartıldığında }\end{array}$ \\
\hline İşin Doğası 1 & 4,1441 & 0,79061 & 0,904 \\
İşin Doğası 2 & 4,2645 & 0,72688 & 0,907 \\
İşin Doğası 3 & 4,0831 & 0,78537 & 0,906 \\
İşin Doğası 4 & 4,0302 & 0,75485 & 0,906 \\
İşin Doğası 5 & 4,3678 & 0,77900 & 0,908 \\
Fiziksel Çalışma Koşulları 1 & 4,0856 & 0,78349 & 0,906 \\
Fiziksel Çalışma Koşulları 2 & 4,2796 & 0,76205 & 0,907 \\
Fiziksel Çalışma Koşulları 3 & 4,0403 & 0,83387 & 0,906 \\
Fiziksel Çalışma Koşulları 4 & 4,1914 & 0,79049 & 0,906 \\
Fiziksel Çalışma Koşulları 5 & 4,0453 & 0,82141 & 0,905 \\
Sosyal Statü 1 & 3,9118 & 0,75531 & 0,907 \\
Sosyal Statü 2 & 3,8766 & 0,78327 & 0,908 \\
Ücret 1 & 4,3023 & 0,72077 & 0,908 \\
Ücret 2 & 4,3300 & 0,73473 & 0,907 \\
Ücret 3 & 4,2292 & 0,76565 & 0,906 \\
Yöneticiler 1 & 3,8564 & 0,76346 & 0,907 \\
Yöneticiler 2 & 3,7733 & 0,80025 & 0,905 \\
Yöneticiler 3 & 3,9899 & 0,77518 & 0,908 \\
Yöneticiler 4 & 3,9320 & 0,76072 & 0,908 \\
Promosyon Fırsatları 1 & 4,1184 & 0,75451 & 0,907 \\
Promosyon Fırsatları 2 & 4,0428 & 0,76256 & 0,909 \\
Sektörde Kalma Niyeti 1 & 3,7708 & 0,76234 & 0,908 \\
Sektörde Kalma Niyeti 2 & 3,8615 & 0,71312 & 0,910 \\
\hline
\end{tabular}




\begin{tabular}{cccc} 
Sektörde Kalma Niyeti 3 & 3,7204 & 0,71061 & 0,908 \\
Sektörde Kalma Niyeti 4 & 3,8665 & 0,74861 & 0,907 \\
\hline Ölçeğin Güvenilirliği & & 0,910
\end{tabular}

Güvenilirlik analizi sonucunda Cronbach's Alpha değeri 0,910 olarak tespit edilmiştir. Buradan hareketle, araştırmada kullanılan ölçeğin güvenilir olduğu yorumunu yapmak mümkündür (Yıldız ve Uzunsakal, 2018: 19).

\subsection{Faktör Analizine İlişkin Bulgular}

Analizin bu aşamasında ölçekte yer alan ifadelere öncelikle açıklayıcı faktör analizi devamında ise doğrulayıcı faktör analizi yapılmıştır. Bu analizlerle birlikte ölçekten çıkarılması gereken ifadeler çıkarılmıştır. Açıklayıcı faktör analizi çalışmalarına başlamadan önce toplanan verilerin açıklayıcı faktör analizine uygun olup olmadığını araştırmak amacıyla KMO (Kaiser-Meyer-Olkin) ve Bartlett's testleri bulguları incelenmiş olup (KMO: 0,862 - Bartlett's: $p<0,010$ ) iki değerin de faktör analizine uygun olduğu saptanmıştır.

Tablo 3. Açıklayıcı Faktör Analizi Bulguları

\begin{tabular}{|c|c|c|c|c|}
\hline IFADELER & $\begin{array}{l}\text { Faktör } \\
\text { Yükü }\end{array}$ & $\begin{array}{l}\text { Açıklanan } \\
\text { Varyans \% }\end{array}$ & $\begin{array}{l}\text { Cronbach's } \\
\text { Alpha }\end{array}$ & Özdeğer \\
\hline \multicolumn{5}{|l|}{ İşin Doğası } \\
\hline Turizm sektöründe yapılan işler eğlencelidir. & 0,702 & 32,032 & 0,853 & 8,008 \\
\hline $\begin{array}{l}\text { Turizm sektöründe yapılan işler çalışanların beklentilerine } \\
\text { uygundur. }\end{array}$ & 0,792 & & & \\
\hline Turizm sektöründe çalışma saatleri çok uzundur. & 0,793 & & & \\
\hline Turizm sektöründe çalışma saatleri düzensizdir. & 0,767 & & & \\
\hline $\begin{array}{l}\text { Turizm sektöründe çalışma saatleri aile yaşamını olumsuz } \\
\text { etkiler. }\end{array}$ & 0,656 & & & \\
\hline \multicolumn{5}{|l|}{ Fiziksel Çevre Koşulları } \\
\hline Turizm sektöründe çalışma ortamı gürültülüdür. & 0,604 & 8,248 & 0,826 & 2,062 \\
\hline Turizm sektöründe fiziksel çalışma koşulları genellikle iyidir. & 0,785 & & & \\
\hline $\begin{array}{l}\text { Turizm sektöründe çalışanların kullandığı alanlar iyi } \\
\text { durumdadır. }\end{array}$ & 0,656 & & & \\
\hline Turizm sektöründe iş kazası riski yüksektir. & 0,574 & & & \\
\hline Turizm sektöründe fiziksel çalışma ortamı temizdir. & 0,779 & & & \\
\hline \multicolumn{5}{|l|}{ Sosyal Statü } \\
\hline Turizm sektörü prestij sahibi bir sektördür. & 0,780 & 4,378 & 0,750 & 1,094 \\
\hline Turizm sektöründe çalışmak toplumda saygı görmektedir. & 0,699 & & & \\
\hline \multicolumn{5}{|l|}{$\ddot{U}$ cret } \\
\hline Turizm sektöründe alınan ücretlerle rahat bir hayat sürülebilir. & 0,632 & 5,457 & 0,740 & 1,364 \\
\hline Turizm sektöründe çalışan ücretleri yeterlidir. & 0,640 & & & \\
\hline $\begin{array}{l}\text { Turizmde alınan ücretler diğer hizmet sektörlerine göre daha } \\
\text { iyi durumdadır. }\end{array}$ & 0,770 & & & \\
\hline \multicolumn{5}{|l|}{ Yöneticiler } \\
\hline Turizm sektöründe yöneticiler çalışanlara eşit davranmaktadır. & 0,709 & 6,580 & 0,756 & 1,645 \\
\hline Turizm sektöründe yöneticiler mesleki eğitim vermektedir. & 0,630 & & & \\
\hline
\end{tabular}


Eskişehir Osmangazi Üniversitesi Sosyal Bilimler Dergisi

Turizm sektöründe yöneticiler çalışanlarına değer 0,716 vermektedir.

Turizm sektöründe yöneticiler çalışanlarına yetki vermektedir.

Promosyon Fırsatları

Turizm sektöründe çalışanların maaş haricinde promosyon $\quad 0,605$

0,571

hakları vardır.

Turizm sektöründe promosyonlar adil dağıtılmaktadır.

Sektörde Kalma Niyeti

$\begin{array}{lllllll}\text { Mezun olduktan sonra turizm sektöründe çalışmayı } & 0,600 & 4,716 & 0,740 & 1,179\end{array}$

düşünüyorum.

Turizm sektöründe uzun yıllar çalışmayı düşünüyorum. $\quad 0,633$

Turizm sektöründe kariyer yapmanın bana çok şey katacağını $\quad 0,594$

düşünüyorum.

Mezun olduktan sonra ne iş yapacağımı biliyorum.

0,577

Toplam Açıklanan Varyans

65,600

Tablo 3'te yer alan açıklayıcı faktör analizi bulguları incelendiğinde, araştırma modeline ve literatüre uygun olarak 7 adet faktörün belirlendiği görülmektedir. Bu 7 faktörlü yapı ise toplam varyansın \%65,6'sını açıklamaktadır. Analiz sonucuna elde edilen 7 adet faktör yine literatüre uygun olarak aşağıdaki gibi adlandırılmıştır (Riegel ve Dallas, 1998; Kusluvan ve Kusluvan, 2000; Richardson, 2010; El-Houshy, 2014):

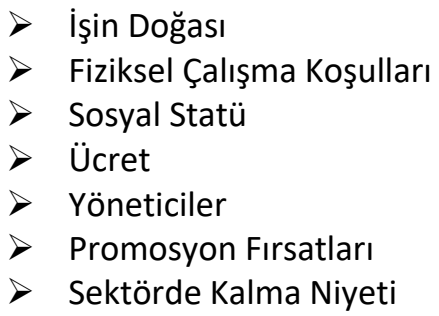

Açıklayıcı faktör analizinin devamında ise analiz sonucu belirlenen yapılara doğrulayıcı faktör analizi yapılmıştır. Doğrulayıcı faktör analizinde 2 adet ifade ölçekten çıkarılmıştır (Şekil 2). 
Şekil 2. Doğrulayıcı Faktör Analizi Bulguları

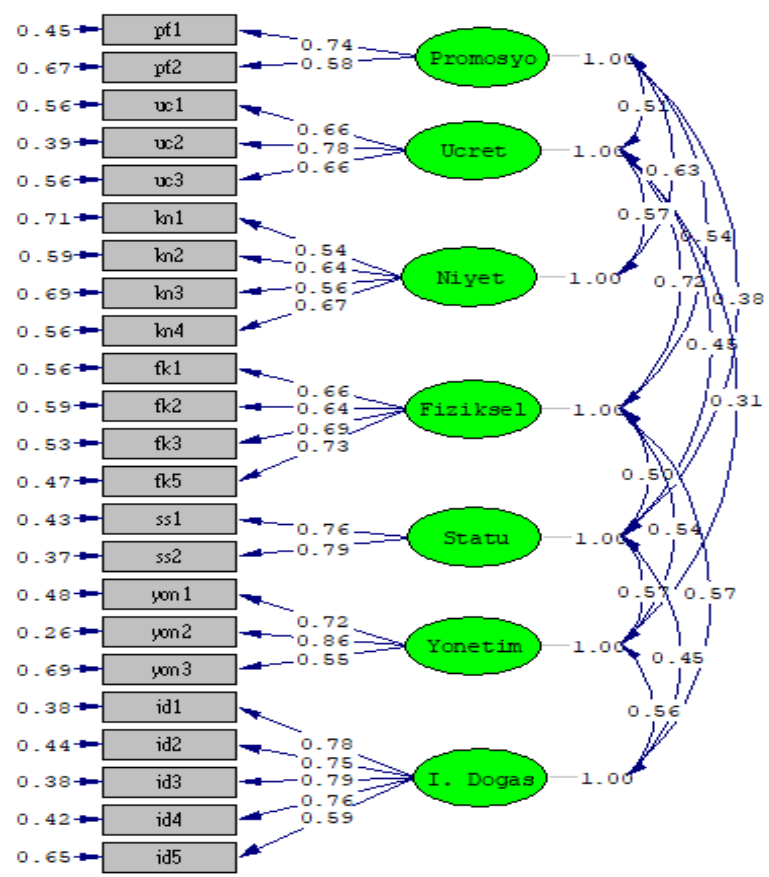

Chi-Square $=608.76, d f=209$, P-value=0.00000, RMSEA=0.076

Şekil 2'de araştırmada kullanılan modele yönelik doğrulayıcı faktör analizi bulguları yer almaktadır. Önerilen modelin doğruluğunun belirlenmesi için ise uyum değerlerine ve standart uyum ölçütlerine bakılmıştır (Tablo 4).

Tablo 4. Önerilen Modelin Uyum Değerleri ve Standart Uyum Ölçütleri

\begin{tabular}{lccc}
\hline \hline Uyum Ölçütleri & iyi Uyum & Kabul Edilebilir Uyum & Model Değeri \\
\hline $\mathrm{x}^{2} / \mathrm{sd}$ & $0 \leq \mathrm{x}^{2} / \mathrm{sd}<2$ & $2 \leq \mathrm{x}^{2} / \mathrm{sd} \leq 3$ & 2,91 \\
$\mathrm{RMSEA}$ & $0 \leq \mathrm{RMSEA}<0,05$ & $0,05 \leq \mathrm{RMSEA} \leq 0,08$ & 0,076 \\
$\mathrm{SRMR}$ & $0 \leq \mathrm{SRMR}<0,05$ & $0,05 \leq \mathrm{SRMR} \leq 0,10$ & 0,057 \\
$\mathrm{NFI}$ & $0,95<\mathrm{NFI} \leq 1,00$ & $0,90 \leq \mathrm{NFI} \leq 0,95^{\mathrm{a}}$ & 0,96 \\
$\mathrm{NNFI}$ & $0,97<\mathrm{NNFI} \leq 1,00$ & $0,95 \leq \mathrm{NNFI} \leq 0,97^{\mathrm{b}}$ & 0,97 \\
$\mathrm{IFI}$ & $0,95<\mathrm{IFI} \leq 1,00$ & $0,90 \leq \mathrm{IFI} \leq 0,95$ & 0,96 \\
$\mathrm{RFI}$ & $0,95<\mathrm{RFI} \leq 1,00$ & $0,90 \leq \mathrm{RFI} \leq 0,95$ & 0,93 \\
$\mathrm{CFI}$ & $0,97<\mathrm{CFI} \leq 1,00$ & $0,95 \leq \mathrm{CFI} \leq 0,97$ & 0,97 \\
GFI & $0,95<\mathrm{GFI} \leq 1,00$ & $0,90 \leq \mathrm{GFI} \leq 0,95$ & 0,91 \\
AGFI & $0,90<\mathrm{AGFI} \leq 1,00$ & $0,85 \leq \mathrm{AGFI} \leq 0,90$ & 0,87 \\
\hline
\end{tabular}


Tablo 4'te önerilen modelin literatürde yaygın olarak kullanılan on standart uyum ölçütü açısından değerlendirilmesi yer almaktadır (Çelik ve Yılmaz, 2016). Buna göre önerilen model için "x2/sd", "RMSEA", "SRMR", "NNFI", "RFI", "CFI", "GFI"” VE "AGFI" değerleri kabul edilebilir uyum göstermektedir. Diğer taraftan "NFI" ve "IFI" değerlerinin ise iyi uyum gösterdiği görülmüştür.

\subsection{Yapısal Eşitlik Modellemesi Bulguları}

Doğrulayıcı faktör analizinin devamında araştırma modelinde yer alan faktörler arasındaki çoklu istatistiki ilişkilerin incelenmesi amacıyla yapısal eşitlik modellemesi yapılmıştır. Modelde "İşin Doğası", "Fiziksel Çalışma Koşulları", "Sosyal Statü", "Ücret", "Yöneticiler" ve "Promosyon Fırsatları" dışsal gizil değişken "Sektörde Kalma Niyeti" içsel gizil değişken olarak yer almaktadır (Şekil 3).

Şekil 3. Yapısal Eşitlik Modellemesi Bulguları (t-değerleri)

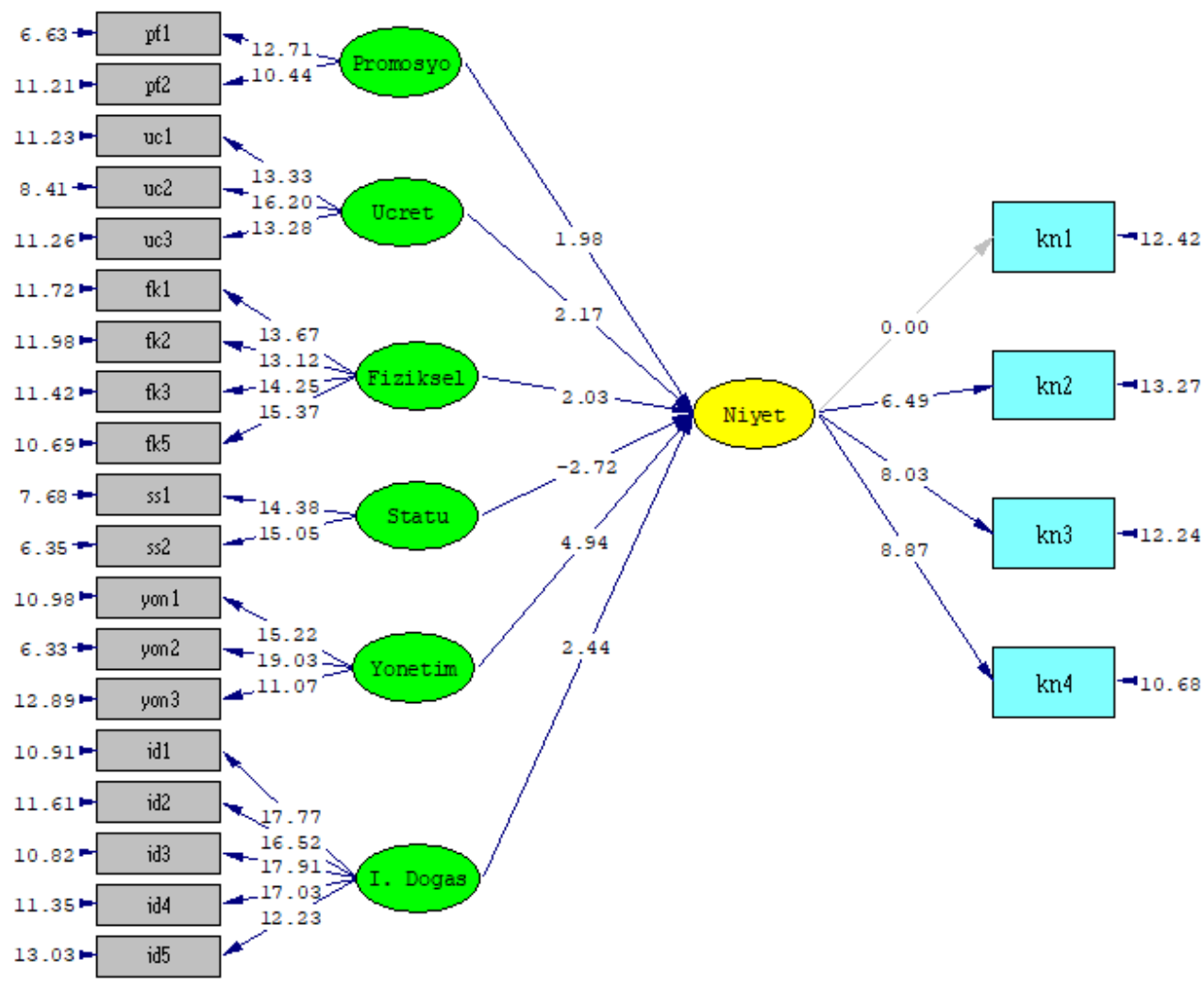

Chi-Square $=608.76, \mathrm{df}=209, \mathrm{P}-\mathrm{value}=0.00000, \mathrm{RMSEA}=0.076$ 
Şekil 3'te yer alan yapısal eşitlik modellemesi analizi sonucunda önerilen model kabul edilmiştir. Analizin devamında ise modelin yapı geçerliliği ve açıklanan varyans değerleri incelenmiştir (Tablo 5).

Tablo 5. Yapı Geçerliliği ve Açıklanan Varyans

\begin{tabular}{|c|c|c|c|c|c|}
\hline Faktörler / Maddeler & $\begin{array}{l}\text { Standart } \\
\text { Yükler }\end{array}$ & t-değeri & $R^{2}$ & $\begin{array}{c}\text { Yapı } \\
\text { Güvenirliliği }\end{array}$ & $\begin{array}{c}\text { Açıklanan } \\
\text { Varyans } \\
\text { (AVE) }\end{array}$ \\
\hline İşin Doğası & & & & 0,86 & 0,55 \\
\hline \multirow[t]{5}{*}{ (iD) } & 0,75 & $10,91^{* * *}$ & 0,5625 & & \\
\hline & 0,78 & $11,61 * * *$ & 0,6084 & & \\
\hline & 0,59 & $10,82 * * *$ & 0,3481 & & \\
\hline & 0,76 & $11,35^{* * *}$ & 0,5776 & & \\
\hline & 0,79 & $13,03 * * *$ & 0,6241 & & \\
\hline Fiziksel Çalışma Koşulları & & & & 0,77 & 0,46 \\
\hline \multirow[t]{4}{*}{$(\mathrm{FÇK})$} & 0,69 & $11,72 * * *$ & 0,4761 & & \\
\hline & 0,73 & $11,98 * * *$ & 0,5329 & & \\
\hline & 0,66 & $11,42 * * *$ & 0,4356 & & \\
\hline & 0,64 & $10,69 * * *$ & 0,4096 & & \\
\hline Sosyal Statü & & & & 0,75 & 0,60 \\
\hline \multirow[t]{2}{*}{ (SS) } & 0,76 & $7,68 * * *$ & 0,5776 & & \\
\hline & 0,79 & $6,35 * * *$ & 0,6241 & & \\
\hline Ücret & & & & 0,74 & 0,49 \\
\hline \multirow[t]{3}{*}{ (ÜC) } & 0,66 & $11,23 * * *$ & 0,4356 & & \\
\hline & 0,78 & $8,41 * * *$ & 0,6084 & & \\
\hline & 0,66 & $11,26 * * *$ & 0,4356 & & \\
\hline Yöneticiler & & & & 0,76 & 0,52 \\
\hline \multirow[t]{3}{*}{ (YÖN) } & 0,72 & $10,98 * * *$ & 0,5184 & & \\
\hline & 0,55 & $6,33 * * *$ & 0,3025 & & \\
\hline & 0,86 & $12,89 * * *$ & 0,7396 & & \\
\hline Promosyon Fırsatları & & & & 0,66 & 0,50 \\
\hline \multirow[t]{3}{*}{$(\mathrm{PF})$} & 0,58 & $6,63 * * *$ & 0,3364 & & \\
\hline & 0,74 & $11,21 * * *$ & 0,5476 & & \\
\hline & & & & 0,72 & 0,40 \\
\hline \multirow{4}{*}{$\begin{array}{l}\text { Sektörde Kalma Niyeti } \\
\text { (SKN) }\end{array}$} & 0,56 & $12,42 * * *$ & 0,3136 & & \\
\hline & 0,67 & $13,27^{* * *}$ & 0,4489 & & \\
\hline & 0,54 & $12,24^{* * *}$ & 0,2916 & & \\
\hline & 0,52 & $10,68 * * *$ & 0,2704 & & \\
\hline Hipotezler & & \multicolumn{4}{|c|}{ Sonuç } \\
\hline$H_{1}: i D \rightarrow S K N$ & 0,21 & $2,44 * *$ & \multicolumn{2}{|c|}{ Desteklendi } & \\
\hline$H_{2}: F C \zeta K \rightarrow S K N$ & 0,20 & $2,03 * *$ & \multicolumn{2}{|c|}{ Desteklendi } & \\
\hline$H_{3}: S S \rightarrow S K N$ & $-0,24$ & $-2,72 * * *$ & \multicolumn{2}{|c|}{ Desteklendi } & \\
\hline$H_{4}: \ddot{U C} \rightarrow S K N$ & 0,25 & $2,17 * *$ & \multicolumn{2}{|c|}{ Desteklendi } & \\
\hline$H_{5}: Y O ̈ N \rightarrow S K N$ & 0,55 & $4,94 * * *$ & \multicolumn{2}{|c|}{ Desteklendi } & \\
\hline$H_{6}: P F \rightarrow S K N$ & 0,19 & $1,98 * *$ & \multicolumn{2}{|c|}{ Desteklendi } & \\
\hline
\end{tabular}


Tablo 5 incelendiğinde, araştırma kapsamında kurulan $H_{1}, H_{2}, H_{3}, H_{4}, H_{5}$ ve $H_{6}$ hipotezlerinin desteklendiği görülmektedir. Buna göre "İşin Doğası", "Fiziksel Çalışma Koşulları", "Sosyal Statü", "Ücret”, "Yöneticiler" ve "Promosyon Fırsatları" dışsal gizil değişkenleri "Sektörde Kalma Niyeti" içsel gizil değişkenini istatistiksel olarak anlamlı bir şekilde etkilemektedir.

Tablo 5'e göre, katılımcıların işin doğasına yönelik algılarındaki bir birimlik artış kariyer niyetinde 0,21 birim, fiziksel çalışma koşullarına yönelik algılarındaki bir birim artış sektörde kalma niyetinde 0,20 birim, ücrete yönelik algılarındaki bir birimlik artış sektörde kalma niyetinde 0,25 birim, yöneticilere yönelik algılarındaki bir birimlik artış sektörde kalma niyetinde 0,55 birim, promosyon fırsatlarına yönelik algılarındaki bir birimlik artış sektörde kalma niyetinde 0,19 birim artış sağlamaktadır. Diğer taraftan, katılımcıların sosyal statüye yönelik algılarındaki bir birimlik artış sektörde kalma niyetlerinde 0,24 birim azalışa neden olmaktadır.

\section{Sonuç ve Öneriler}

Emek yoğun bir sektör olarak kabul edilen turizmde hizmet kalitesi algısı yaratmak büyük bir önem teşkil etmektedir. Bunun sağlanabilmesi için de sektörde istihdam edilen insan gücünün kalifiye olması gerekmektedir. Bu noktada da hizmet kalitesinin odak noktasını oluşturan tüketici beklentilerini karşılayacak kalifiye elemanların eğitimini üstlenen kurumlara önemli bir rol düşmektedir. Bu çalışmada da Eskişehir Osmangazi Üniversitesi Turizm Fakültesi'nde öğrenim gören öğrencilerin turizm sektörüne yönelik algılarının sektörde kalma niyetlerine etkisinin ve öğrencilerin sektörde kalma niyetlerini en çok etkileyen unsurların belirlenmesi amaçlanmıştır.

Araştırma sonucunda katılımcıların turizm sektörüne yönelik; işin doğası, fiziksel çalışma koşulları, sosyal statü, ücret, yöneticiler ve promosyon fırsatları algılarının sektörde kalma niyetleri üzerinde istatistiksel olarak anlamlı bir etkisi olduğu tespit edilmiş ve kurulan 6 hipotez de desteklenmiştir. Bu yönüyle yapılan araştırma, literatürde yer alan diğer çalışmalarla da paralellik göstermektedir (Riegel ve Dallas, 1998; Kusluvan ve Kusluvan, 2000; Richardson, 2010; El-Houshy, 2014).

Araştırma bulguları incelendiğinde katılımcıların sektörde kalma niyetlerini en fazla etkileyen değişkenin yöneticilere yönelik algılar ( $\left.t=4,94^{* * *} ; p<0,010\right)$ olduğu görülmüştür. Buna göre katılımcıların yöneticilere yönelik algılarında yaşanan bir birimlik artış sektörde kalma niyetlerini 0,55 birim arttırmaktadır. Diğer bir ifadeyle, katılımcıların yöneticileri ile kurdukları ilişkiler sektörde kalma niyetleri üzerinde büyük bir öneme sahiptir. Ayrıca katılımcıların sektörde devam etme niyetlerinin işin doğası $\left(t=2,44^{* *} ; p<0,050\right)$, ücret $\left(t=2,17^{* *} ; \quad p<0,050\right)$, fiziksel çalışma koşulları $\left(t=2,03^{* *} ; p<0,050\right)$ ve promosyon fırsatlarına $\left(t=1,98^{* *} ; p<0,050\right)$ yönelik algılarını da pozitif yönlü olarak etkilediği tespit edilmiştir. 
Araştırma sonucunda elde edilen bir diğer bulgu ise katılımcıların turizm sektörüne yönelik sosyal statü algılarının sektörde kalma niyeti üzerinde negatif yönlü bir etkisi olduğudur ( $t=-2,72 * * * ; p<0,010)$. Buna göre katılımcıların turizm sektöründen algıladıkları sosyal statüdeki bir birimlik artış sektörde kalma niyetlerini 0,24 birim azaltmaktadır. Diğer bir ifadeyle, sosyal statüye yönelik algıları sektörde kalma niyetlerini olumsuz bir şekilde etkilemektedir. Araştırmada sosyal statü; turizm sektörü prestij sahibi bir sektörüdür ve turizm sektöründe çalışmak toplumda saygı görmektedir ifadeleri ile ölçülmüştür. Bu ifadelerle sektörde kalma niyetinin negatif yönlü olması katılımcıların turizme yönelik sosyal statü algılarının sektörde kalmalarının önünde önemli bir engel olduğunu ortaya koymaktadır. Bu noktada da eğitim veren kurumlara ve turizm anlamında karar vericilere önemli görevler düşmektedir. Öğrencilere sektörün dinamiklerinin daha iyi anlatılması gerekmektedir. Bunun yanı sıra sektörde kalifiye personellerin istihdamının az olmasının bir diğer nedeni de turizm mesleği ile ilgili bir meslek yasasının bulunmamasıdır. Turizm meslek yasasının çıkarılması ile sektörde kalifiye personel çalıştırma oranları artırılabilir böylece turizm ile ilgili fakülte/meslek okulları mezunlarının sektörde çalışma oranları yükseltilebilir. Bu gelişmeler sektörün ve turizm mesleklerinin prestijini ve itibarını artıracak ve toplum tarafından daha saygın bir meslek grubu olarak algılanmasına neden olacaktır.

Araştırma kapsamında incelenen diğer bir husus da işin doğası, fiziksel çalışma koşulları, sosyal statü, ücret, yöneticiler, promosyon fırsatları ve sektörde kalma niyeti faktörlerinin katılımcıların cinsiyet, yaş, öğrenim yılı ve sektör tecrübelerine göre anlamlı farklılık gösterip göstermediğidir. Bu kapsamda ilgili faktörlerin cinsiyete göre anlamlı farklılık gösterip göstermediği t-testi aracılığıyla incelenmiştir. Yapılan t-testi sonucunda sektörde kalma niyetinin cinsiyete göre anlamlı farklılık gösterdiği tespit edilmiştir $(p<0,050)$. Buna göre erkek katılımcıların $(\bar{x}=4,3368)$ sektörde kalma niyetleri kadın katılımcılara $(\bar{x}=4,0021)$ göre daha yüksektir. Bu sonuç Chuang ve Dellmann-Jenkins (2010) çalışması ile benzerlik göstermektedir. Diğer değişkenler ise cinsiyete göre anlamlı bir farklılık göstermemektedir.

Araştırmanın devamında katılımcıların işin doğası, fiziksel çalışma koşulları, sosyal statü, ücret, yöneticiler, promosyon fırsatları ve sektörde kalma niyeti faktörlerine yönelik algılarında sektör tecrübelerine göre anlamlı farklılık gösterip göstermediği varyans analizi (one-way anova) aracılığıyla incelenmiştir. Analiz sonucunda ise katılımcıların işin doğası $(p=0,00)$, promosyon fırsatları $(p=0,01)$ ve yöneticilere $(p=0,42)$ yönelik algının sektör tecrübelerine göre anlamlı farklılık gösterdiği tespit edilmiştir $(p<0,050)$. Farklılığın nereden kaynaklandığının tespit edilmesinde ise Tukey testinden yararlanılmıştır. İlgili farklılıkların ise üç faktörde de 1 yıldan az tecrübesi olanlar ile 4 yıldan fazla tecrübesi olanlardan kaynaklandığı görülmüştür. Bu bulgu, Roney ve Öztin (2007) tarafından yapılan araştırmayla da benzerlik göstermektedir. 
Araştırma kapsamında incelenen diğer bir husus ise işin doğası, fiziksel çalışma koşulları, sosyal statü, ücret, yöneticiler, promosyon fırsatları ve sektörde kalma niyeti faktörlerine yönelik algıların katılımcıların yaşlarına ve öğrenim sürelerine göre anlamlı farklılık gösterip göstermediğidir. Yapılan varyans analizi sonucunda ise ilgili değişkenler açısından anlamlı bir farklılık tespit edilememiştir $(p>0,050)$.

Ileride yapılacak olan araştırmalarda bu çalışma kapsamında kurulan modele farklı değişkenler eklenmesinin veya mevcut modelde yer alan değişkenler arasındaki aracılık rollerinin incelenmesinin de literatüre katkı sağlayacağı düşünülmektedir. Ayrıca ileride yapılacak olan araştırmalarda bu çalışmada kullanılan modelin farklı örneklemlere uygulanmasının da literatüre katkı sağlayacağı düşünülmektedir.

\section{Araştırma ve Yayın Etiği Beyanı}

Araştırma verilerinin toplanmasında kullanılan anket formu için ESOGÜ Sosyal ve Beşeri Bilimler Bilimsel Araştırma ve Yayın Etiği Kurulu Başkanlığı'ndan etik kurul onayı alınmıştır.

\section{Yazarların Makaleye Katkı Oranları}

1. Yazar (\%35), 2. Yazar (\%33) ve 3. Yazar (\%32).

\section{Çıkar Beyanı}

Makalenin yazarları arasında herhangi bir çıkar çatışması bulunmamaktadır.

\section{Kaynaklar}

Baltacı, F., Üngüren, E., Avsallı, H. ve Demirel, H.N. (2012). Turizm Eğitimi Alan Öğrencilerin Eğitim Memnuniyetlerinin ve Geleceğe Yönelik Bakış Açılarının Belirlemesine Yönelik Bir Araştırma, Uluslararası Alanya Iş̧letme Fakültesi Dergisi, 4(1), 17-25.

Brown, J., Leeuwen, H. D. ve Mitch, D. (2004). The History of the Modern Career: An Introduction, Sidney: Ashgate Publishing Company.

Burack E.H. (1988). Career Management in Organizations: A Practical Human Resources Planning, Lake Forest: Brace-Park Press.

Cano, J.A., Tabares, A. ve Alvares, C. (2017). University Students' Career Choice Intentions: Guesss Colombia Study, Espacios, 38(5), 1-20.

Chuang, N.K. ve Dellmann-Jenkins, M. (2010). Career Decision Making and Intention: A Study of Hospitality Undergraduate Students, Journal of Hospitality \& Tourism Research, 34, ss. 512-530. https://doi.org/10.1177/1096348010370867.

Çelik, H.E. ve Yılmaz, V. (2016). Lisrel 9.1 ile Yapısal Eşitlik Modellemesi, Ankara: Anı Yayıncilık.

Çıngı, H. (2009). Örnekleme Kuramı, Ankara: Bizim Büro Basımevi Yayın ve Dağıtım.

El-Houshy, S. (2014). Hospitality Students Perceptions Towards Working in Hotels: A Case Study of the Faculty of Tourism and Hotels in Alexandria University, Tourism in a 
Changing World: Opportunities \& Challenges, The 6th International Scientific Conference, 800-818, Alexandria, Mısır.

Erbaş, A., Cankül, D. ve Temizkan, R. (2013). Turizm Personeli Meslek Yasası Girişimi: Tiyader Örneği, 14. Ulusal Turizm Kongresi, 1150-1162, Kayseri, Türkiye.

Farmaki, A. (2018). Tourism and Hospitality Internships: A Prologue to Career Intentions?, Journal of Hospitality, Leisure, Sport \& Tourism Education, 23, 50-58.

Greenhaus, J.H. ve Callanan, G.A. (2006). Encyclopedia of Career Development, New Delhi: A Sage Reference Publication.

Gunawardena, L., Hemachandra, D. ve Kodıthuwakku, S.S. (2018). Career Intention of Undergraduate Students: An Application of Theory of Planned Behavior, IUP Journal of Entrepreneurship Development, 15(1), 7-27.

Hartzenberg, J.S. (2002). The Implementation of Career Management Practices in the African Public Service, 15 Şubat 2020 tarihinde Pretoria Üniversitesi: https://repository.up.ac.za/bitstream/handle/2263/26928/00dissertation.pdf?seque nce $=1$ \&isAllowed $=y$ adresinden alındı.

Haven-Tang, C. ve Jones, E. (2008). Labour Market and Skills Needs of the Tourism and Related Sectors in Wales, International Journal of Tourism Research, 5(2), 13-35.

Hayes, K.D. ve Ninemier, D.J. (2008). Human Resources Management in the Hospitality Industry, New Jersey: John Wiley \& Sons.

Herr, E.L. (2001). Career Development and its Practice: A Historical Perspective, The Career Development Quarterly, 49, 196-211.

Kozak, N., Akoğlan Kozak, M. ve Kozak, M. (2014). Genel Turizm Bilgisi, Ankara: Detay Yayıncılık.

Köşker, H. ve Unur, K. (2017). Turizm Lisans Öğrencilerinin Turizm Sektöründe Çalışma Eğilimleri Üzerine Bir Araştırma, Seyahat ve Otel İ̧̧letmeciliği Dergisi, 14(2), 126-141.

Kusluvan, S. ve Kusluvan, Z. (2000). Perceptions and Attitudes of Undergraduate Tourism Students Towards Working in the Tourism Industry in Turkey, Tourism Management, 21(3), 251-269.

Patrick, H.A. ve Kumar, A. (2011). Career Management, Employee Development and Performance in Indian Information Technology Organizations, Business Management Dynamics, 1(5), 24-31.

Richardson, S. (2010). Tourism and Hospitality Students' Perceptions of a Career in the Industry: A Comparison of Domestic (Australian) Students and International Students Studying in Australia, Journal of Hospitality and Tourism Management, 17(1), 1-11.

Riegel, C. Ve Dalllas, M. (1998). Hospitality and Tourism Careers: A Blue Print for Success, New Jersey: Prentice Hall.

Roney, S. A. ve Öztin, P. (2007). Career Perceptions of Undergraduate Tourism Students: A Case Study in Turkey, Journal of Hospitality, Leisure, Sport \& Tourism Education, 6(1), 4-17. 
Szivas, E., Rıley, M. ve Airey, D. (2003). Labor Mobility into Tourism Attraction and Satisfaction, Annals of Tourism Research, 30(1), 64-76.

Sullivan, S.E. ve Baruch, Y. (2009). Advances in Career Theory and Research: A Critical Review and Agenda for Future Exploration, Journal of Management, 35(6), 1542-1571.

Şahin, I. ve Fındık, T. (2008). Türkiye'de Mesleki ve Teknik Eğitim: Mevcut Durum, Sorunlar ve Çözüm Önerileri, Türkiye Sosyal Araştırmalar Dergisi, 12(3), 65-86.

Şit, M. (2016). Türkiye'de Turizm Sektörünün İstihdama Katkısı, Akademik Yaklaşımlar Dergisi, 7(1), 101-117.

Tavakol, M. ve Dennick, R. (2011). Making Sense of Cronbach's Alpha, International Journal of Medical Education, 2, 53-55.

Temizkan, S.P., Ceviz, Ç. ve Cankül, D. (2019). Turizm Eğitimi Lisans Mezunları ve İstihdam Durumları. Gastroia: Journal of Gastronomy and Travel Research, 3(3), 437-461.

Turizm Akademisyenleri Derneği (2019) YKS Turizm Yerleştirme istatistikleri 1 Şubat 2020 tarihinde https://tuader.org/2019/09/11/2019-yks-turizm-yerlestirme-istatistikleri/ adresinden alındı.

Türker, N., Uçar, M. ve Ateş, M.A. (2016). Turizm Eğitimi Alan Öğrencilerin Turizm Sektörü Algıları: Karabük Üniversitesi Öğrencileri Üzerine bir Araştırma, Karabük Üniversitesi Sosyal Bilimler Enstitüsü Dergisi, 6(2), 311-333.

Yıldız, D. ve Uzunsakal, E. (2018). Alan Araştırmalarında Güvenilirlik Testlerinin Karşılaştırılması ve Tarımsal Veriler Üzerine Bir Uygulama, Uygulamalı Sosyal Bilimler Dergisi, 1, 14-28.

Warshaw, P.R. ve Davis, F.D. (1985). Disentangling Behavioral Intention and Behavioral Expectation, Journal of Experimental Social Psychology, 21(3), 213-228. 